\title{
PENGGUNAAN BAHAN PENGEMULSI ALGINAT DAN SUBSTITUSI TEPUNG KENTANG PADA PEMBUATAN BAKSO IKAN GABUS (Channa striata)
}

\author{
Hefti Salis Yufidasari $^{\text {a,b, } * \text {, Happy Nursyam }}{ }^{\mathrm{a}, \mathrm{b}}$, Belinda Putri Ardianti ${ }^{\mathrm{a}}$ \\ ${ }^{\mathrm{a}}$ Teknologi Hasil Perikanan, FPIK, Universitas Brawijaya, Jl. Veteran, Malang, Indonesia \\ ${ }^{\mathrm{b}}$ Kelompok Kajian Bio-Seafood, FPIK, Universitas Brawijaya, Jl. Veteran, Malang, Indonesia \\ *Correspondent Author : hefti_salis@ub.ac.id
}

\begin{abstract}
Abstrak
Bakso ikan merupakan salah satu produk olahan yang menggunakan daging ikan sebagai bahan baku utama produk. Bahan baku yang dapat digunakan adalah ikan gabus (Channa striata). Ikan gabus memiliki kandungan protein yang cukup tinggi, akan tetapi memiliki kandungan air yang tinggi pula, sehingga jika diolah menjadi bakso, dibutuhkan bahan tambahan lain yang dapat memperbaiki tekstrur dari bakso ikan tersebut. Penggunaan Alginat dapat berperan sebagai emulsifier, sedangkan tepung kentang dapat berperan untuk memperbaki tekstur bakso yang dihasilkan. Tujuan dari penelitian ini adalah untuk mengetahui karakteristik bakso ikan gabus (Channa striata) yang ditambahkan alginat dan substitusi tepung kentang. Metode yang digunakan dalam penelitian ini adalah metode eksperimen dengan rancangan percobaan 2 faktor, yaitu faktor pertama penambahan alginate $(0 \% ; 0,75 \% ; 1 \%)$ dan faktor kedua substitusi tepung kentang $(0 \% ; 5 \% ; 7,5 \% ; 10 \% ; 12,5 \%)$ dengan 3 kali ulangan. Hasil penelitian terbaik ditunjukkan pada bakso ikan gabus dengan penambahan $1 \%$ alginat dan 7,5\% tepung kentang; dengan hasil analisis karakteristik yaitu kekerasan 1,28 N, kekenyalan sebesar $0,005 \mathrm{~kg} / \mathrm{mm}^{2}$, kadar protein 20,24\%; kadar air $61,01 \%$, kadar lemak 1,22\%, kadar abu 1,43\%, kadar karbohidrat 16,10\%, dan $\mathrm{a}_{\mathrm{w}}$ sebesar 0,84 . Hasil analisis karakteristik organoleptik yaitu rasa 6,3 warna 6,77 tekstur 6,3 dan aroma 6,3. Saran yang diberikan adalah, perlu diketahui berapa lama masa simpan dari bakso tersebut.
\end{abstract}

Kata Kunci: Alginat, Bakso ikan, Ikan gabus (Channa striata), Tepung Kentang.

Abstract

Fish meatball is one of the products that use fish meat as the main raw material. The raw material that can be used is snakehead fish (Channa striata). Snakehead fish has a high protein, but also has a high water content, so if it is processed into meatballs, additional ingredients are needed that can improve the texture of the fish meatballs. The use of Alginate can act as an emulsifier, while potato flour can play a role in improving the texture of the meatballs. This study aimed to determine the characteristics of snakehead fish meatball that added with alginate and substitution of potato flour. The method used in this study was an experimental method with 2 experimental designs, the first factor adding alginate (0\%; 0,75\%; 1\%) and the second factor substitution of potato flour $(0 \% ; 5 \% ; 7,5 \% ; 10 \% ; 12,5 \%)$. The best results were shown on snakehead fish meatballs with the addition of 1\% alginate and 7,5\% potato flour with 1,28 $\mathrm{N}$ of hardness, elasticity of $0,005 \mathrm{~kg} / \mathrm{mm}^{2}$, protein content of 20,24\%; moisture content $61,01 \%$, fat content 1,22\%, ash content $1,43 \%$, carbohydrate content $16,10 \%, a_{w} 0,84$. The values of organoleptic characteristics were 6,3 colors 6,77 texture 6,3 and aroma 6,3. The advice given is, it is necessary to know how long the shelf life of the meatballs is.

Keywords: Alginate, Fish Meatballs, Potato Flour, Snakehead Fish (Channa striata).

\section{PENDAHULUAN}

Bakso ikan adalah produk olahan daging ikan cacah yang telah diproses dan diemulsikan dengan bahan tambahan lain, dicetak berbentuk bulat yang kemudian dimasak dalam air panas. Faktor-faktor yang perlu diperhatikan untuk menghasilkan produk bakso ikan dengan kualitas baik, antara lain jenis daging, kualitas daging, jenis tepung, dan perbandingan antara daging dan tepung yang digunakan [1]. Jenis ikan yang bisa digunakan sebagai bahan baku pembuatan bakso ikan, diantaranya adalah ikan gabus (Channa striata). 
Ikan gabus memiliki ciri khas yang tidak dimiliki oleh jenis ikan tawar lainnya, yaitu memiliki kandungan albumin yang cukup tinggi, mengandung protein myofibril dan merupakan jenis ikan yang tidak mengandung elastin serta jaringan ikat yang terdapat pada dagingnya juga sedikit [2]. Hal ini yang menyebabkan protein pada ikan gabus menjadi mudah dicerna. Akan tetapi, kadar air yang terdapat pada ikan gabus juga cukup tinggi yaitu sebesar 69\% [3], sehingga, dibutuhkan bahan tambahan lain yang dapat meningkatkan daya ikat air untuk menghasilkan tekstur yang lebih baik pada pembuatan bakso ikan. Bahan tambahan tersebut dapat berupa menggunakan alginat dan tepung kentang.

Alginat terdapat dalam semua jenis algae coklat (phaeophyta). Alginat merupakan suatu kopolimer linear dimana terdiri dari dua unit monomerik, yaitu asam D-mannuronat dan asam L-guluronat. Alginat memiliki fungsi bermacam-macam baik dibidang pangan maupun non-pangan [4]. Salah satu contoh manfaat dari alginat yang dapat diterapkan dalam bidang pangan yaitu sebagai emulsifier. Proses emulsi bakso terbentuk pada saat proses pembuatan adonan, sehingga kestabilan emulsi dalam pembuatan bakso perlu dipertahankan. Ketidakstabilan emulsi atau pemecahan emulsi dapat terjadi pada saat pengolahan.

Proses pembuatan bakso selain memperhatikan proses emulsinya, tingkat kekenyalan dari produk tersebut juga penting. Bakso ikan yang berkualitas baik selain memiliki gizi yang tinggi, juga harus memiliki tingkat kekenyalan atau tekstur yang tepat. Oleh sebab itu, tepung kentang merupakan salah satu alternatif bahan yang dapat digunakan sebagai substitusi tepung tapioka yang dapat memperbaiki tekstur dari bakso ikan. Tepung kentang memiliki kemampuan mengikat sejumlah besar air yang membuat ukuran granulanya dapat mengembang (swelling power) lebih besar yaitu $1153 \mathrm{~g} / \mathrm{g}$ sedangkan tepung tapioka hanya sebesar 71 g/g [5]. Hasil penelitian terdahulu diketahui bahwa, substitusi tepung kentang dengan konsentrasi $7,5 \%$ yang diaplikasikan pada bakso ikan lele merupakan konsentrasi terbaik dan dapat memperbaiki teksturnya [6]. Oleh karena itu, penambahan alginat dan substitusi tepung kentang pada produk bakso ikan gabus ini diharapkan mampu memperbaiki tekstur dari bakso ikan gabus.

\section{MATERI DAN METODE}

\section{Materi Penelitian}

Alat-alat yang digunakan pada penelitian ini adalah pisau, talenan, parutan, baskom, blender, beaker glass $500 \mathrm{ml}$, timbangan analitik, spatula, ayakan 80 mesh, oven, crushable tang dan loyang, baskom, sendok takar, food processor, kompor dan panci. Bahan-bahan yang digunakan pada penelitian ini adalah ikan gabus (Channa striata), kentang (Solanum tuberosum), alginat, natrium metabisulfit, aquades, tepung tapioka, gula, garam, lada, ketumbar, dan MSG.

\section{Metode Penelitian}

Metode yang digunakan dalam penelitian ini adalah metode eksperimen dengan rancangan percobaan 2 faktor, yaitu faktor pertama penambahan alginate $(0 \% ; 0.75 \%$; $1 \%)$ dan faktor kedua substitusi tepung kentang $(0 \% ; 5 \% ; 7.5 \% ; 10 \% ; 12.5 \%)$ dengan 3 kali ulangan.

\section{Proses Pembuatan Tepung kentang}

Proses pembuatan tepung kentang dengan modifikasi [7], diawali dengan pengupasan dan pencucian kentang sampai bersih, kemudian dipotong dengan ketebalan kurang lebih 1-2 mm dengan menggunakan pemarut, selanjutnya dicuci kembali untuk membersihkan sisa-sisa kotoran yang masih tertinggal. Kentang parut direndam menggunakan natrium metabisulfit dengan konsentrasi 500 ppm selama 45 menit. Natrium metabisulfit berfungsi sebagai pemutih, penghambat bakteri, kapang, dan khamir. Proses selanjutnya adalah dioven dengan suhu $60^{\circ} \mathrm{C}$ selama \pm 4 jam, setelah kentang kering, lalu dihaluskan menggunakan blender dan diayak menggunakan ayakan 80 mesh. Tepung kentang yang dihasilkan 
kemudian dilakukan pengujian meliputi uji proksimat, amilosa dan amilopektin.

\section{Prosedur penelitian}

Penelitian ini dilakukan berdasar pada penelitian sebelumnya dengan modifikasi [8][6]. Langkah awal yang dilakukan adalah persiapan bahan baku berupa daging ikan gabus dicuci hingga bersih, kemudian ditimbang sebanyak $300 \mathrm{~g}$ dan digiling bersama dengan es batu sebanyak $75 \mathrm{~g}$ menggunakan food processor. Langkah selanjutnya, ditambahkan bumbu-bumbu berupa garam $6 \mathrm{~g}$, gula $3 \mathrm{~g}$, lada $1 \mathrm{~g}$, ketumbar $1 \mathrm{~g}$, dan bawang putih $5 \mathrm{~g}$ dan digiling kembali hingga bumbu dan daging tecampur merata; setelah itu ditambahkan tepung tapioka pada tiap-tiap perlakuan, $(15 \% ; 10 \%$; $7,5 \% ; 5 \% ; 2,5 \%)$, lalu tepung kentang dan alginat sesuai dengan konsentrasi yang telah ditentukan dan digiling kembali hingga adonan tercampur merata. Langkah berikutnya yaitu adonan dibentuk bulat-bulat dan direbus dalam air mendidih selama 10-15 menit hingga bakso mengapung sebagai tanda bahwa bakso telah matang. Bakso ikan ditiriskan dan diuji proksimat, aktivitas air $\left(a_{\mathrm{w}}\right)$, kekerasan, kekenyalan dan organoleptik.

\section{HASIL DAN PEMBAHASAN}

\section{Karakteristik Tepung Kentang}

Hasil analisis kimia tepung kentang yang digunakan sebagai bahan substitusi pada produk bakso ikan gabus dapat dilihat pada Tabel 1.

Tabel 1. Analisa Kimia Tepung Kentang

\begin{tabular}{clcc}
\hline No & $\begin{array}{c}\text { Parameter } \\
\text { Kimia }\end{array}$ & $\begin{array}{c}\text { Hasil } \\
(\boldsymbol{\%})\end{array}$ & $\begin{array}{c}\text { Pembanding } \\
(\mathbf{\%})\end{array}$ \\
\hline 1 & Air & 7,76 & $7,61^{\mathrm{a}}$ \\
2 & Protein & 6,04 & $7,91^{\mathrm{a}}$ \\
3 & Lemak & 0,16 & - \\
4 & Abu & 3,44 & $2,7^{\mathrm{a}}$ \\
5 & Karbohidrat & 82,60 & $71,94^{\mathrm{a}}$ \\
6 & Amilosa & 31,32 & $20^{\mathrm{b}}$ \\
7 & Amilopektin & 68,68 & $80^{\mathrm{b}}$ \\
\hline
\end{tabular}

Sumber: a) [9] dan b) [10]
Tabel 1. memperlihatkan bahwa kadar amilopektin pada tepung kentang lebih tinggi dibandingkan dengan kadar amilosanya. Amilosa memiliki struktur yang linear dan sedikit bercabang [11], oleh karena itu amilosa memiliki sifat kekentalan yang lebih tinggi dan merupakan fraksi terlarut. Hal tersebut dikarenakan amilosa banyak mengandung gugus hidroksil. Amilopektin memiliki struktur yang bercabang [12]. Hal tersebut menyebabkan struktur granulanya lebih kompak, ruang udara antar granula dan ukuran granula lebih besar, sehingga amilopektin memiliki sifat gel yang lunak dan kelengketan yang cukup tinggi. Sifat tersebut yang dibutuhkan dalam produk bakso ikan.

\section{Karakteristik Bakso Ikan Gabus dengan Penambahan Alginat dan Tepung kentang}

\section{Hasil Analisis Kadar Air}

Hasil analisis kadar air bakso ikan gabus dengan penambahan alginat dan substitusi tepung kentang dapat dilihat pada Gambar 1.

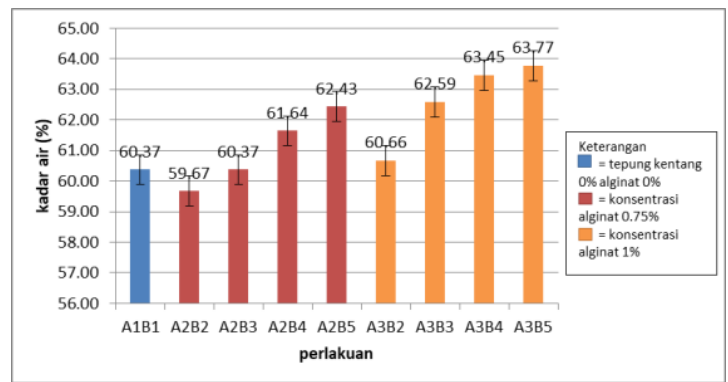

Gambar 1. Grafik Kadar Air

Kadar air pada sampel bakso ikan gabus berkisar antara 59,67\% - 63,77\%; cenderung meningkat seiring dengan meningkatnya konsentrasi penambahan alginat dan substitusi tepung kentang, akan tetapi masih sesuai dengan kriteria yang ditetapkan [13], yaitu maksimal kadar air sebesar 65\%. Tepung kentang memiliki sifat daya ikat air yang cukup besar sehingga dapat menyebabkan produk yang dihasilkan memiliki kadar air yang tinggi. Hal tersebut dikarenakan, bagian yang paling berperan dalan penyerapan air dari biomasa adalah kandungan amilosa dan amilopektin, yang keduanya merupakan komponen pati [6]. Kedua komponen pati 
tersebut berperan dalam proses gelatinisasi. Pada proses gelatinisasi akan terjadi pemutusan ikatan hidrogen yang akan menyebabkan air masuk ke dalam granula pati sehingga terjadi pengembangan granula pati [14]. Alginat juga memiliki kemampuan menyerap air dengan membentuk gel [4]. Hal tersebut dikarenakan protein dan gel polisakarida akan membentuk jembatan hidrogen yang mana akan menjebak air didalamnya sehingga pada produk bakso ikan gabus, air yang terkandung di dalamnya akan terperangkap dalam matriks alginat [15].

\section{Hasil analisis Kadar Protein}

Hasil analisis kadar protein bakso ikan gabus dengan penambahan alginat dan substitusi tepung kentang dapat dilihat pada Gambar 2.

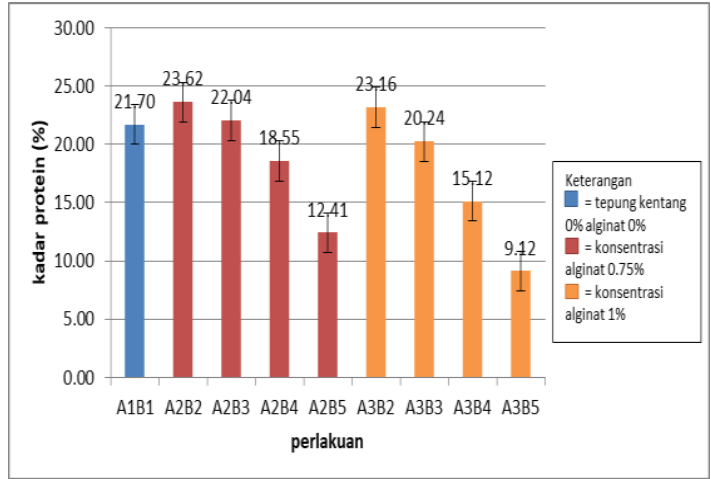

Gambar 2. Grafik Kadar Protein

Kadar protein pada sampel bakso ikan gabus berkisar antara $23,62 \%-9,12 \%$. Hal tersebut sesuai dengan kriteria yang ditetapkan SNI, yaitu minimal sebesar 9\% [13]. Gambar 2 menunjukkan bahwa semakin tinggi konsentrasi alginat dan tepung kentang yang ditambahkan maka semakin kecil kadar protein pada sampel bakso ikan gabus. Hal tersebut disebabkan oleh bertambahnya kadar air pada bahan pangan, maka kandungan senyawa lain seperti protein dan karbohidrat akan memiliki persentase yang lebih rendah, begitu pula sebaliknya [16]. Pengikatan air yang terjadi pada proses gelatinisasi antara tepung kentang dan air dapat meningkatkan kadar air dalam bahan dan menyebabkan kadar protein pada bahan menurun [4].

\section{Hasil Analisis Kadar Lemak}

Hasil analisis kadar lemak bakso ikan gabus dengan penambahan alginat dan substitusi tepung kentang dapat dilihat pada Gambar 3.

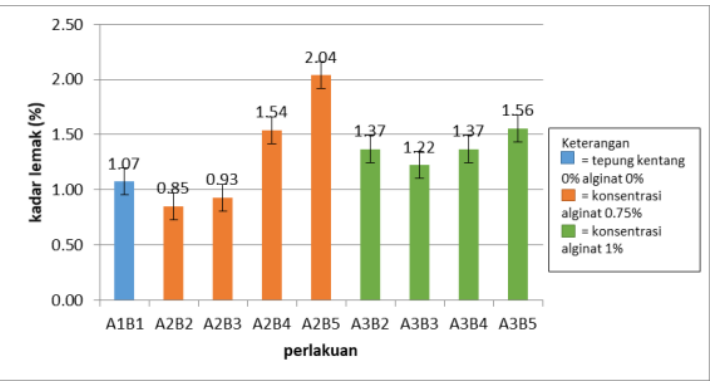

Gambar 3. Grafik Kadar Lemak

Nilai Kadar lemak hasil analisis keragaman kadar lemak pada sampel bakso ikan gabus berkisar antara 0,85\% - 2,04\%. Nilai ini masih cenderung cukup tinggi dibandingkan nilai kadar lemak pada bakso menurut SNI yaitu maksimal 1\% [17]. Gambar 3 menunjukkan peningkatan kadar lemak berjalan seiring dengan meningkatnya konsentrasi penambahan alginat dan substitusi tepung kentang. Alginat dan tepung kentang memiliki sifat yang sama yaitu mudah mengikat molekul air. Alginat merupakan jenis polisakarida hidrokoloid yang akan berinteraksi dengan protein sehingga dapat membentuk gel; demikian juga dengan pengaruh substitusi tepung kentang, sehingga semakin tinggi konsentrasi alginat dan tepung kentang yang digunakan maka semakin banyak juga air dan lemak yang tertahan dan menyebabkan kadar lemak menjadi naik.

\section{Hasil Kadar Abu.}

Hasil analisis kadar abu bakso ikan gabus dengan penambahan alginat dan substitusi tepung kentang dapat dilihat pada Gambar 4.

Kadar abu pada sampel bakso ikan gabus berkisar antara 1,21\% - 2,04\%, hal ini sesuai dengan kriteria yang ditetapkan SNI, yaitu maksimal sebesar 2\% [13].

Gambar 4 menunjukkan nilai kadar abu pada sampel bakso ikan gabus cenderung 
meningkat seiring dengan meningkatnya konsentrasi penambahan alginat dan substitusi tepung kentang akan tetapi peningkatan antara tiap sampel tidak jauh berbeda. Hal tersebut dikarenakan kadar abu pada tepung kentang yang digunakan sebagai bahan tambahan juga cukup tinggi yaitu sebesar 3,44\%. Kadar abu dalam bahan pangan berasal dari zat anorganik sisa pembakaran, selain itu juga dapat berasal dari banyaknya kadar garam dan bahan aditif lainnya [18].

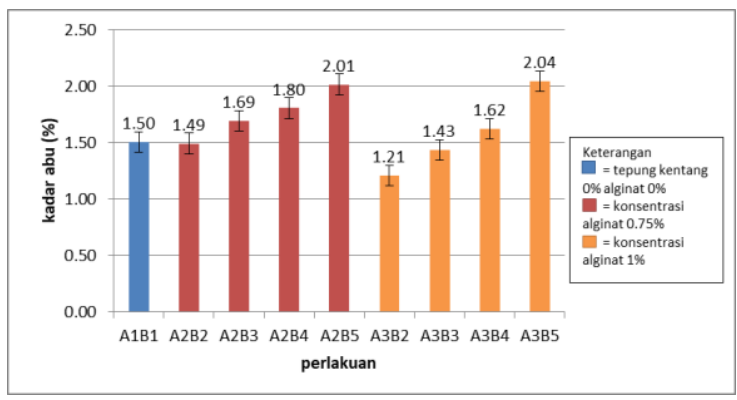

Gambar 4. Grafik Kadar Abu

\section{Hasil Analisis Kadar Karbohidrat.}

Hasil analisis kadar karbohidrat bakso ikan gabus dengan penambahan alginat dan substitusi tepung kentang dapat dilihat pada Gambar 5.

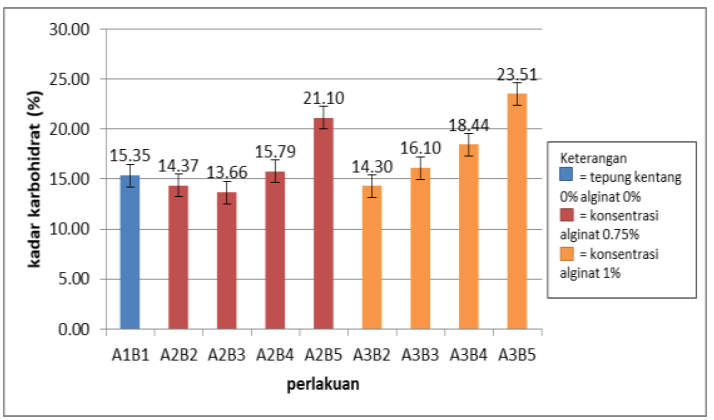

Gambar 5. Grafik Kadar Karbohidrat

Nilai kadar karbohidrat pada sampel bakso ikan gabus cenderung meningkat seiring dengan meningkatnya konsentrasi penambahan alginat dan konsentrasi tepung kentang yang disubstitusikan. Hal tersebut dikarenakan kadar karbohidrat tepung kentang cukup tinggi sehingga dapat meningkatkan kadar karbohidrat pada bakso ikan gabus. Semakin tinggi penambahan konsentrasi alginat maka kadar karbohidrat pada produk juga semakin tinggi. Alginat merupakan bahan yang kaya akan serat, dimana serat terhitung sebagai karbohidrat [8]. Perhitungan kadar karbohidrat yang digunakan pada penelitian ini menggunakan metode by difference yang mana kadar gizi lainnya seperti protein, air, abu dan lemak akan mempengaruhi hasil dari kadar karbohidrat.

\section{Hasil Analisis $\mathbf{a}_{\mathbf{w}}$}

Hasil analisis kadar $\mathrm{a}_{\mathrm{w}}$ bakso ikan gabus dengan penambahan alginat dan substitusi tepung kentang dapat dilihat pada Gambar 6.

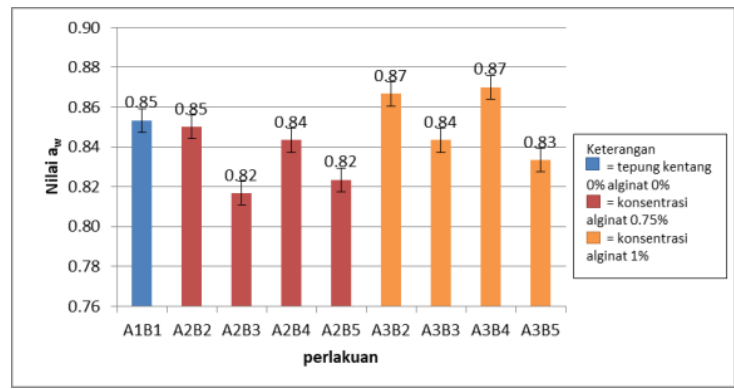

Gambar 6. Grafik Nilai $\mathrm{a}_{\mathrm{w}}$

Nilai $a_{w}$ pada sampel bakso ikan gabus berkisar antara $0,82 \%$ - 0,87\%. Faktor penyebab tinggi rendahnya nilai $\mathrm{a}_{\mathrm{w}}$ pada suatu bahan pangan yang tidak stabil dikarenakan kelembaban pada sampel dan pada lingkungan yang tidak stabil. Oleh karena itu, semakin tinggi nilai $\mathrm{a}_{\mathrm{w}}$ pada suatu bahan maka semakin banyak pula kemungkinan bakteri dapat tumbuh. Produk olahan daging akan memiliki masa simpan relatif lama jika mempunyai $a_{w}$ dibawah 0,91 [19]. Hal ini mengindikasikan bahwa bakso yang dihasilkan berpotensi sebagai media pertumbuhan kapang dan khamir, dikarenakan memang produk bakso termasuk dalam kategori produk basah sehingga cukup besar potensi digunakan sebagai media pertumbuhan kapang dan khamir. Oleh karena itu bakso harus disimpan pada suhu beku [20].

\section{Hasil Analisa Uji Kekerasan}

Hasil analisis kadar kekerasan bakso ikan gabus dengan penambahan alginat dan 
substitusi tepung kentang dapat dilihat pada Gambar 7.

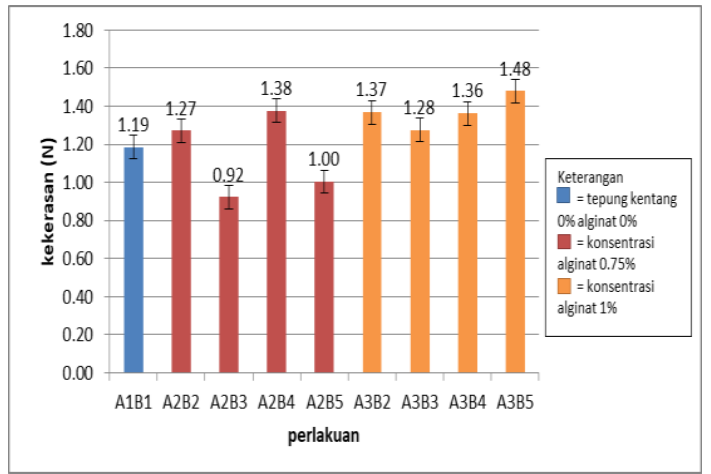

Gambar 7. Grafik Nilai Tingkat Kekerasan

Nilai kekerasan pada sampel bakso ikan gabus berkisar antara 0,92-1,48 N. Gambar 7 menunjukkan bahwa nilai kekerasan pada sampel bakso ikan gabus cenderung meningkat seiring dengan meningkatnya konsentrasi penambahan alginat dan substitusi tepung kentang. Hal tersebut dikarenakan struktur matriks dari pati lebih rapat dibandingkan dengan matriks protein. Selain faktor pati, selama proses pemasakan panas menyebabkan denaturasi protein myofibril daging terutama kompleks actomyosin sehingga daging menjadi keras karena serat otot mengalami penyusutan, sedangkan keempukan terjadi karena pelarutan jaringan penghubung [21].

Tekstur kekerasan yang dihasilkan pada suatu produk juga erat hubungannya dengan proses gelatinisasi yang terjadi. Suhu gelatinisasi pada tepung kentang berkisar antara $58-65^{\circ} \mathrm{C}$ [22]. Pada saat pati mengalami proses gelatinisasi maka granula pati akan menarik air yang berada disekitar sehingga menghasilkan gel yang kuat. Rantai-rantai panjang dari protein membentuk jaringan tiga dimensi dalam matrik gel yang keteguhannya dipertahankan oleh gaya Van der waals, ikatan hidrogen dan mungkin juga oleh ikatan kovalen [23].

\section{Hasil Analisis Uji Kekenyalan}

Pengukuran kekenyalan didasarkan pada prinsip kemampuan suatu bahan untuk melakukan deformasi elastis. Hasil analisis kadar kekenyalan bakso ikan gabus dengan penambahan alginat dan substitusi tepung kentang dapat dilihat pada Gambar 8.

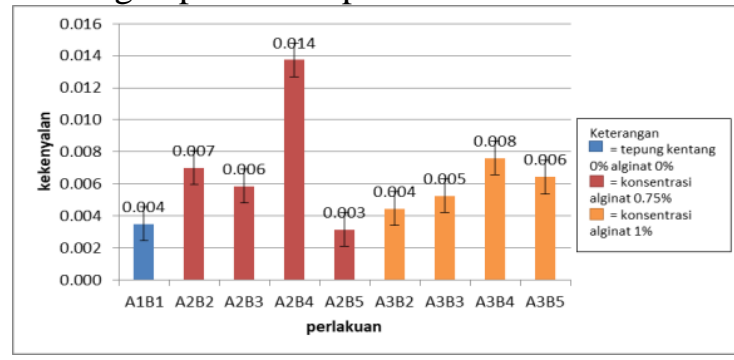

Gambar 8. Grafik Nilai Tingkat Kekenyalan

Gambar 8 tersebut menunjukkan bahwa perlakuan penambahan alginat $1 \%$ dapat mempertahankan kestabilan tekstur bakso ikan gabus sampai dengan perlakuan tepung kentang $10 \%$. Apabila dilakukan substitusi tepung kentang diatas 10\%, maka untuk konsentrasi alginatnya perlu juga ditambahkan untuk mendapatkan kestabilan tekstur yang baik pula. Konsentrasi alginat yang digunakan untuk diaplikasikan pada gel makanan berkisar antara $0,5 \%$ hingga $1,5 \%$. Kekenyalan suatu poduk atau bahan pangan diukur berdasarkan kemampuan bahan tersebut untuk melakukan deformasi elastis [24]. Kekenyalan ditentukan oleh jenis daging, bahan dan bumbu yang ditambahkan [25]. Semakin banyak jumlah pati yang ditambahkan ke dalam formula produk pada batas-batas tertentu, terjadi interaksi ikatan yang kuat antara pati, air dan protein, sehingga meningkatkan kekenyalan produk [23].

\section{Hasil Analisis Organoleptik}

Analisis organoleptik ini dilakukan untuk mengetahui apakah produk bakso ikan gabus dapat diterima oleh panelis, yang meliputi 4 parameter yaitu rasa, warna, tekstur dan aroma. Hasil uji Kruskal Wallis menunjukkan bahwa semua perlakuan penambahan alginat dan substitusi tepung kentang pada bakso ikan gabus tidak memberikan pengaruh yang nyata terhadap hedonik rasa, aroma dan warna $(\mathrm{P}>0,05)$. Hasil uji hedonik tekstur menunjukkan bahwa, perlakuan memberikan pengaruh yang nyata $(\mathrm{P}<0,05)$, artinya panelis menilai bahwa ada perbedaan terhadap parameter tekstur pada bakso ikan gabus 
dengan penambahan alginat dan substitusi tepung kentang. Perlakuan penambahan alginat dan substitusi tepung kentang pada bakso ikan gabus yang paling disukai oleh panelis adalah dengan penambahan konsentrasi alginat sebesar $1 \%$ dan konsentrasi tepung kentang sebesar 5\%, yang berarti produk bakso ikan gabus memiliki tekstur padat, kompak dan agak kenyal. Hasil tersebut sesuai dengan hasil penelitian sebelumnya bahwa, penambahan tepung kentang berpengaruh nyata terhadap tekstur dari bakso ikan, dikarenakan tesktur pada bakso ikan terbentuk oleh adanya matriks 3 dimensi, yaitu terjadinya ikatan silang antara protein myofibril pada daging ikan gabus dengan pati dari tepung sehingga membentuk jembatan disulfida, yang berperan pada pembentukkan gel, sehingga membentuk tekstur bakso ikan yang kenyal dan kokoh [6].

\section{KESIMPULAN}

Hasil penelitian mengenai penggunaan alginat dan substitusi tepung kentang pada pembuatan bakso ikan gabus dapat diambil kesimpulan bahwa, perlakuan terbaik pada perlakuan penambahan alginate $1 \%$ dan tepung kentang 5\% dengan hasil analisis karakteristik fisikokimia yaitu kadar protein $23,16 \%$ kadar air $60,66 \%$, kadar lemak $1,37 \%$, kadar abu $1,21 \%$, kadar karbohidrat $14,30 \%, a_{\mathrm{w}} 0,87$, kekerasan $1,37 \mathrm{~N}$ dan kekenyalan sebesar $0,004 \mathrm{~kg} / \mathrm{mm}^{2}$, sedangkan hasil uji organoleptik yaitu rasa 6,57 warna 6,8 tekstur 7,27 dan aroma 6,6. Saran yang diberikan adalah, perlu dilakukan pengujian tentang berapa lama masa simpan dari bakso ikan gabus tersebut.

\section{DAFTAR PUSTAKA}

[1] N. M. Pratiwi, I Widiastuti, A. Baehaki, "Karakterisitik Fisiko-Kimia dan Sensori Bakso Ikan Gabus (Channa striata) dengan Penambahan Genjer (Limnocharis flava)", Jurnal Teknologi Hasil Perikanan, vol. 5, no. 2, hal. 178189, 2016.
[2] A.G. Purwosari, "Pengaruh penggunaan jenis dan jumlah bahan pengisi terhadap hasil jadi sosis ikan gabus (Channa striata)", E-Journal Boga, vol. 5, no. 1, hal. 211-228, 2016.

[3] E. Suprayitno, "Misteri Ikan Gabus", Universitas Brawijaya Press, Malang, 2017.

[4] A. P. Utomo, P. H. Riyadi, dan I. Wijayanti, "Aplikasi alginat sebagai emulsifier di dalam pembuatan kamaboko ikan kuniran (Upeneus sulphureus) pada penyimpanan suhu ruang", JPBHP, vol. 3, no. 1, hal. 127136, 2014.

[5] J. N. Bemiller, dan R. L. Whitsler, "Starch Chemistry and Technology", Elsevier Inc, USA, Page. 452, 2009.

[6] M. A. Rahussidi, Sumardianto, dan I. Wijayanti, "Pengaruh perbandingan konsentrasi tepung tapioka (Manihot uttilissima) dan tepung kentang (Solanum tuberosum) terhadap kualitas bakso ikan lele (Clarias batrachus)", $J$. Peng. \& Biotek. Hasil Pi, vol. 5, no. 3, 2006.

[7] A. Simamora, S. Ismed, dan Y. Era, "Pengaruh lama pengeringan kentang dan perbandingan tepung terigu dan tepung kentang terhadap mutu cookies kentang", J. Rekayasa Pangan dan Pert., vol. 2, no. 2, 2014.

[8] W. D. Wardani, Kawiji, dan J. M. Godras, "Isolasi dan karakterisasi natrium alginat dari rumput laut Sargassum sp. untuk pembuatan bakso ikan tenggiri (Scomberomorus commerson)", Biofarmasi, vol. 7, no. 2, hal. 59-67, 2009.

[9] I. T. Anova, H. Wilsa, dan Silfia, "Substitusi tepung terigu dengan tepung kentang (Solanum sp) pada pembuatan cookies kentang", Jurnal Litbang 
Industri, vol. 4, no. 2, hal. 123-131, 2014.

[10] L. H. Meyer, "Food Chemistry", Reinhold Publishing Corparation, Japan, 1971.

[11] Semejin, C. dan PL Buwalda. "Potato Starch", Chapter. 9, 2018.

[12] P. Luna, H. Herawati, S. Widowati, dan A.B. Prianto, "Pengaruh kandungan amilosa terhadap karakteristik fisik dan organoleptik nasi instan", Jurnal Penelitian Pascapanen Pertanian, vol. 12, no. 1, hal. 1-10, 2015.

[13] Standar Nasional Indonesia, "Bakso Ikan", SNI 7266, 2014.

[14] D. D. A. Krisna, "Pengaruh Regelatinasi Dan Modifikasi Hidrotermal Terhadap Sifat Fisik Pada Pembuatan Edible Film Dari Pati Kacang Merah (Vigna angularis sp.)", Tesis, Magister Teknik Kimia Universitas Diponegoro, 2011.

[15] D. Koesoemawardani, dan M. Ali "Rusip dengan penambahan alginat sebagai bumbu", Jurnal Pengolahan Hasil Perikanan Indonesia, vol. 19, no. 3, hal, 277-287, 2016.

[16] M. Lisa, M. Lutfi, dan B. Susilo, "Pengaruh suhu dan lama pengeringan terhadap mutu tepung jamur tiram putih (Plaerotus ostreatus)", Jurnal Keteknikan Pertanian Tropis dan Biosistem, vol. 3, no. 3, hal. 270-279, 2015.

[17] Standar Nasional Indonesia (SNI), "Bakso Ikan", no. 01-3451, 1995

[18] F.G. Winarno, "Kimia Pangan dan Gizi", PT. Gramedia Pustaka Utama, Jakarta, 2004.
[19] M. Ismail, R. Kautsar, P. Sembada., S. Aslimah, dan L. I. Arief, "Kualitas fisik dan mikrobiologis bakso daging sapi pada penyimpanan suhu yang berbeda", Jurnal Ilmu Produksi dan Teknologi Hasil Peternakan, vol. 4, no. 3, hal. 372374, 2016.

[20] S. K. Wahono, E. Damayanti, V. T. Rosyida, dan E. I. Sadyastuti, "Laju pertumbuhan Saccharomyces cerevisiae pada proses fermentasi pembentukan bioetanol dari biji sorgum (Sorghum bicolor L.)", Seminar Rekayasa Kimia dan Proses, ISSN: 1411-4216, Juli 2011.

[21] R. Usman, "Karakteristik Fisik Kimia Dan Organoleptik Bakso Daging Sapi Dengan Penambahan Tepung Porang (Amorpophallus oncophyllus)", Skripsi, Institut Pertanian Bogor, 2014.

[22] O. R. Fennema, "Food Chemistry Third Edition", Marcel Dekker Inc, United State of America, 1996.

[23] P. H. Riyadi, "Pemanfaatan ikan beloso sebagai bahan baku pembuatan pasta ikan dengan penambahan tepung garut", Jurnal Saintek Perikanan, vol. 2, no. 1, hal. 8-21, 2006.

[24] D. W. S. Wong, "Mechanism and Theory in Food Chemistry", Second Edition, Springer, California, 2018.

[25] N. H. Riyadi, dan W. Atmaka, "Diversifikasi dan karakterisasi citarasa bakso ikan tenggiri (Scomberomus commerson) dengan penambahan asap cair tempurung kelapa", Jurnal Teknologi Hasil Pertanian, vol. 3, no. 1, 2010. 